\title{
Evaluation of silicon oil on bacterial growth
}

\author{
Avaliação dos efeitos do óleo de silicone no crescimento bacteriano
}

Fabio Adams $^{1}$, Ivana lopes Romero², Cely Barreto da Silva ${ }^{3}$, Roberta Pereira de Almeida Manzano ${ }^{4}$

\begin{abstract}
Purpose: To analyze the antimicrobial properties of silicon oil (Óleo de Silicone ${ }^{\circledR}$ Ophthalmos, Brazil) on in vitro bacterial growth of different microorganisms related to endophthalmitis.

Methods:The following microorganisms were analyzed:(1) Pseudomonas aeruginosa (ATCC 27583); (2) Escherichia coli (ATCC 25922); (3) Staphylococcus aureus (ATCC 25923); (4) Staphylococcus epidermidis (ATCC 12228); (5) Candida albicans (ATCC 10231); (6) Klebsiella pneumoniae (ATCC 13883); and (7) Streptococcus pneumoniae (ATCC 49619). The plates were incubated at $35 \pm 2^{\circ} \mathrm{C}$ and its growth examined after 24 hours. An empty disk was placed in the center of each plate as a control.

Results: No inhibition halos were verified in any of the plates containing the four different concentrations of the bacterial inocula.

Conclusions: The silicon oil 1000 cps does not have any effect on bacterial growth of any of the studied microrganisms.
\end{abstract}

Keywords: Endophthalmitis; Silicon oils/analysis; Anti-infective agents; Bactericides; Antibacterial agents

\section{RESUMO}

Objetivo: Analisar as propriedades antimicrobianas do óleo de silicone (Óleo de Silicone ${ }^{\circledR}$, Ophthalmos, Brazil) no crescimento in vitro de diferentes microrganismos relacionados à endoftalmite.

Métodos: Os seguintes microrganismosforam analisados:(1)Pseudomonas aeruginosa (ATCC 27583); (2) Escherichia coli (ATCC 25922); (3) Staphylococcus aureus (ATCC 25923); (4) Staphylococcus epidermidis (ATCC 12228); (5) Candida albicans (ATCC 10231); (6) Klebsiella pneumoniae (ATCC 13883); and (7) Streptococcus pneumoniae (ATCC 49619). As placas foram incubadas à temperatura de $35 \pm 2^{\circ} \mathrm{C}$ e o seu crescimento examinado após 24 horas. Um disco de papel filtro neutro, sem óleo de silicone, foi posicionado no centro de cada placa como controle.

Resultados: Não foramencontrados halos de inibição em nenhuma das placas contendo as diferentes concentrações de inóculo bacteriano estudadas.

Conclusões: OÓleo de Silicone ${ }^{\circledR} 1000$ cps não apresenta efeito no crescimento bacteriano de nenhum dos microrganismos estudados.

Descritores: Endoftalmite; Óleos de silicone/análise; Antimicrobianos; Bactericidas; Antibacterianos

\section{INTRODUCTION}

Silicon oil is a term designated to denominate a group of clear, inert and hydrophobic polymers, chemically derived from siloxane ${ }^{(1-4)}$. The first reference of its use in ophthalmology dates back to 1958 with Stone, as a substitute of the vitreous humor in experimental intraocular surgery. But it was only after the 1970's, with modern microsurgery, that this technique was widely spread around the world, Jean Haute (France), Relja Zivojnovic (Holand) and Peter Lever (England) combined successfully intraocular injection of the silicon oil and pars plana vitrectomy. Currently, the main indications of its use are complicated cases, when long term tampon effects are required, and infectious endophthalmitis ${ }^{(1-6)}$.

One of the most important indications and reason of this study is the infectious endophthalmitis, the most feared complication of the ophthalmological surgeons. According to previous studies, exogenous endophthalmitis incidence is higher in cases of ocular trauma $(2.4-8 \%)$, trabeculectomy $(0.2-9.6 \%)$ and cataract surgery $(0.04-$ $0.7 \%)$. In the event of an ocular trauma with intraocular foreign body, the incidence increases up to $30 \%$, according to some authors s $^{(3,4,7-24)}$.

The most frequently responsible microorganisms of acute exogenous endophthalmitis are Staphylococcus aureus, Staphylococcus epidermidis, Enterococcus faecalis and Streptococcus pneumoniae. As for the chronic, the most isolated microorganism in cultures is the Propionibacterium acnes ${ }^{(18,22)}$.

Some prospective and experimental studies, both in vitro and in vivo, suggested that the silicon oil has bactericidal activity against many microorganisms, besides increasing the intraocular concentrations of antibiotics, if present ${ }^{(25-29)}$

The purpose of this study was to verify the effect of the silicon oil on in vitro bacterial growth of selected microrganisms.

\section{METHODS}

An experimental study was developed in the Laboratory of Microbiology of the Irmandade da Santa Casa de Misericódia de São Paulo of the Departament of Pathology Sciences of the Faculdade de Ciências Médicas da Santa Casa de Misericórdia de São Paulo (Brazil).

The silicon oil 1000 cps (Óleo de Silicone ${ }^{\circledR}$, Ophthalmos, Brazil) was studied.

The following bacterial cultures from the American Type Culture Collection were studied: Pseudomonas aeruginosa (ATCC 27583), Escherichia coli (ATCC 25922), Staphylococcus aureus (ATCC 25923), Sta-
Submitted for publication: December 22, 2010

Accepted for publication: January 19, 2012

Study carried out at Santa Casa de Misericórdia de São Paulo (SP), Brazil.

${ }^{1}$ Physician, Cataract Service, Department of Ophthalmology, Santa Casa de Misericórdia de São Paulo SCMSP - São Paulo (SP), Brazil.

2 Physician, Postgraduation student, Medical School, Santa Casa de São Paulo - FCMSCSP - São Paulo (SP), Brazil.

3 Pharmaceutical Biochemistry, Santa Casa de Misericórdia de São Paulo - SCMSP - São Paulo (SP), Brazil.

${ }^{4}$ Physician, Retina Service, Department of Ophthalmology, Santa Casa de Misericórdia de São Paulo SCMSP - São Paulo (SP), Brazil.
Funding: No specific financial support was available for this study.

Disclosure of potential conflicts of interest: F.Adams, None; I.L.Romero, None; C.B.Silva, None; R.P.A.Manzano, None.

Correspondence address: Fabio Adams. Rua Bennet, 319 - São Paulo (SP) - 05464-030 - Brazil E-mail: Fabio adams@hotmail.com 
phylococcus epidermidis (ATCC 12228), Candida albicans (ATCC 10231), Klebsiella pneumoniae (ATCC 13883) and Streptococcus pneumoniae (ATCC 49619).

The bacteria were primarily incubated for $18-24 \mathrm{~h}$ in a nutrient broth at $35 \pm 2^{\circ} \mathrm{C}$ until reaching 0.5 on the McFarland scale, which corresponds to $1.5 \times 10^{8} \mathrm{CFU} / \mathrm{Cc}$ (Colony Forming Units) in Tryptic Soy Broth. For each microrganism, three more dilutions were used, corresponding to $1.5 \times 10^{6} \mathrm{CFU} / \mathrm{CC}, 1.5 \times 10^{4} \mathrm{CFU} / \mathrm{CC}$ and $1.5 \times 10^{2} \mathrm{CFU} / \mathrm{CC}$. The four dilutions were submitted to the test.

The four dilutions of the inocula were then seeded on plates containing Muller-Hinton medium for all bacteria with exception of S. pneumoniae, which was seeded on blood agar, according to the modified Kirby-Bauer technique, standardized by the Clinical and Laboratory Standards Institute (C.L.S.I. ${ }^{(30)}$.

Following the preparation of the plates, $15 \mu \mathrm{m}^{3}$ of the silicon oil (Óleo de Silicone ${ }^{\circledR} 1000$ cps, Opthalmos, Brazil) were evenly distributed in standard $6 \mathrm{~mm}$ paper filter discs using micropipettes (Eppendorf $^{\circledR}$, Hamburg, Germany).

The discs containing silicon oil were then positioned in the respective seeded plates, with ten discs for each microrganism, in each of the four different concentrations of bacterial inocula ${ }^{(31)}$.

The plates were once again incubated for 48 hours at $35 \pm 2^{\circ} \mathrm{C}$. The analyses were made in 24 and 48 hours. Bactericidal and bacteriostatic activity was verified by sampling inhibition zones, when present, and seeding other plate with substrates from within the inhibition halos ${ }^{(31)}$

In all plates, a blank paper filter disk was placed without silicon oil, to compare the bacterial growth, since it does not have an inhibition halo.

\section{RESULTS}

No inhibition halos were verified in any of the plates containing the four different concentrations of the bacterial inocula as shown in figure 1.

\section{DISCUSSION}

In our study, in disagreement with other authors, the silicon oil did not have any effect on growth of any of the three main families of ethiological agents of the infeccious endophthalmitis: Gram + bacteria, Gram - bacteria and yeast ${ }^{(26,27)}$. Such a radical difference can be explained by the choice of distinct methods.

Mackiewicz et al. and Ozdamar et al., compared, using similar methods, the growth of different bacteria inoculated directly on silicon oil, saline solution and a nutrition solution. After the adequate

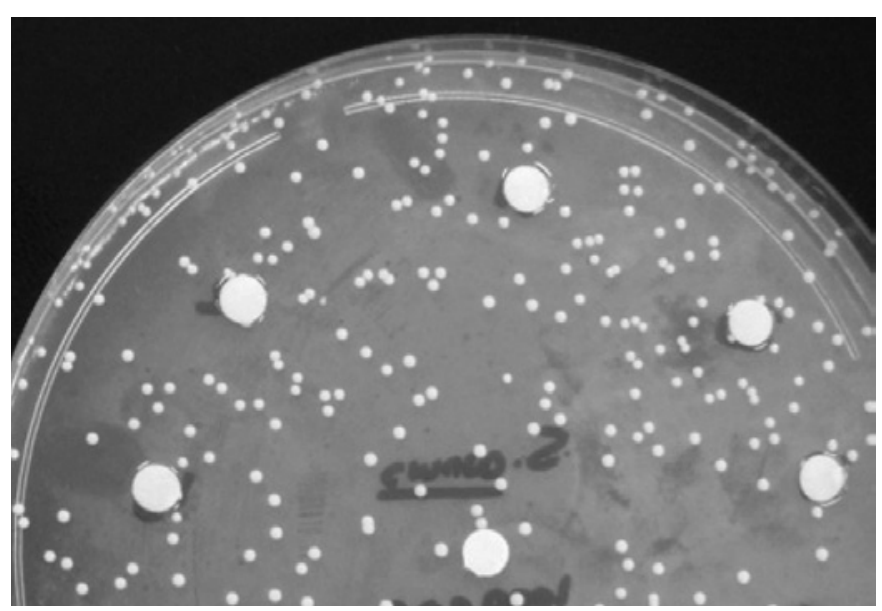

Figure 1. Müeller-Hinton plate inoculated with Staphylococcus aureus showing, in detail, the absence of inhibition halos around the impregnated discs. Laboratory of the Irmandade da Santa Casa de Misericórdia de São Paulo. management of the material and incubation, checking daily the colony forming units, it was verified in both studies that after $5-7$ days, the number of C.F.U. inoculated on silicon oil diminished through time and were extinct after approximately 20 days. On the nutrition solution this outcome was according to the natural growth pattern and, on the saline solution, it was stable throughout the length of the study ${ }^{(26,27)}$.

Nonetheless, these results do not seem to be reproduced in vivo. Bali et al., in 2003, demonstrated that eyes affected with severe acute infectious endophthalmitis treated with pars plana vitrectomy, antibiotics and injection of intraocular silicon oil had better anatomical and functional results when compared with eyes treated only with regular vitrectomy and antibiotics. These results suggest that this substance is useful in the surgical treatment of the infectious endophthalmitis (25)

If in vitro there is no confirmed antimicrobial activity of the silicon oil, the only possible explanation for the above results in vivo would be the nutritional deprivation that the substitution of the vitreous with silicon oil could cause to the intraocular pathogens, leading them to death by starvation and consequently the control of the infection process.

The most probable explanation for the different results of this study relies on the method. The use of filter paper discs on the evaluation of antimicrobial activity is proven to be a very easy method, with high sensitivity and specificity, since it analyzes solely the effect of the studied substance in direct and homogeneous contact with the microorganisms in growth. Other authors have chosen this method to assess the antimicrobial activity of different substances used daily in clinical and surgical practice, such as trypan blue, fluorescein and cyanoacrylate, obtaining reliable results ${ }^{(32-34)}$.

Through this method, we did not observe the presence of inhibition halos around the paper filter discs soaked with silicon oil in any of the plates containing the different concentrations of bacterial inocula, suggesting that the silicon oil at 1000 cps does no have any effect on in vitro bacterial growth.

\section{REFERENCES}

1. Gallemore RP, McCuen BW. Silicon oil in vitreoretinal surgery. In: Ryan SJ, editor. Retina. $4^{\text {th }}$ ed. St. Louis: Mosby; 2006. p.2211-34.

2. Kertes PJ, Peyman GA. Use of silicone oil in vitreous surgery. In: Peyman GA, Meffert SA, Conway MD, Chou F, editors. Vitreoretinal surgical techniques. Londres: Martin Dunitz; 2001. p.193-206.

3. Parel JM, Milne P, Gaultier S, Jallet V, Villain F. Silicon oils: physicochemical properties, In: Ryan SJ, editor. Retina. $4^{\text {th }}$ ed. St. Louis: Mosby; 2006. p.2191-210.

4. Rao NA, Cousins S, Forster D, Meisler D, Opremcap EM, Turgeon P. Intraocular inflammation and uveítis. In: Weingeist TA, Liesegang TJ, Gilbert Grand M, editors. Basic and clinical science course. American Academy of Ophtalmology. 1999-2000. p.119-40.

5. Ambresin A, Wolfensberger TJ, Bovey EH. Management of giant retinal tears with vitrectomy, internal tamponade, and peripheral 360 degrees retinal photocoagulation. Retina. 2003;23(5):622-8

6. Azen SP, Boone DC, Barlos W, McCuen BW, Walonker AF, Anderson MM, et al. Methods, statistical features, and baseline results of a standardized, multicentered ophthalmologic surgical trial: the Silicone Study. Control Clin Trials. 1991;12(3):438-55.

7. Aaberg TM Jr, Flynn HW Jr, Schiffman J, Newton J. Nosocomial acute-onset postoperative endophthalmitis survey. A 10-year review of incidence and outcomes. Ophthalmology. 1998;105(6):1004-10

8. Ciulla TA. Update on acute and chronic endophthalmitis. Ophthalmology. 1999; 106(12):2237-8. Comment on Ophthalmology. 1999;106(12):2395-401.

9. Ciulla TA, Starr MB, Masket S. Bacterial endophthalmitis prophylaxis for cataract surgery: an evidence-based update. Ophthalmology. 2002;109(1):13-24. Comment in Ophthalmology. 2003;110(8):1668; author reply 1669. Ophthalmology. 2003;110(8):1667; author reply 1667-8.

10. Egger SF, Buxbaum A, Georgopoulos M, Sholda C, Vecsei VP, Huber-Spitzy V, Georgopoulos A. Bacterial growth in human vitreous humor. Exp Eye Res. 1997;65(6):791-5.

11. Essex RW, Yi Q, Charles PG, Allen PJ. Post-traumatic endophthalmitis. Ophthalmology. 2004;111(11):2015-22. Comment in Ophthalmology. 2005;112(10):1845-6; author reply 1846-7.

12. Miño de Kaspar H, Neubauer AS, Molnar A, Hoepfner AS, Ta CN, Grasbon T, et al. Rapid direct antibiotic susceptibility testing in endophthalmitis. Ophthalmology. 2002; 109(4):687-93

13. Khan RI, Kennedy S, Barry P. Incidence of presumed postoperative endophthalmitis in Dublin for a 5-year period (1997-2001). J Cataract Refractive Surg. 2005;31(8):1575-81. 
14. Kresloff MS, Castellarin AA, Zarbin MA. Endophthalmitis. Surv Ophthalmol. 1998 43(3):193-224.

15. Kunimoto DY, Das T, Sharma S, Jalali S, Majji AB, Gopinatan U, et al. Microbiology spectrum and susceptibility of isolates: part I. Postoperative endophthalmitis. Endophthalmitis Research Group. Am J Ophthalmol. 1999;128(2):240-2.

16. Miller JJ, Scott IU, Flynn HW Jr, Smiddy WE, Newton J, Miller D, Acute-onset endophthalmitis after cataract surgery (2000-2004): incidence, clinical settings, and visua outcomes after treatment. Am J Ophthalmol. 2005;139(6):983-7. Comment in Am J Ophthalmol. 2005;139(6):1097-8.

17. Ng JQ, Morlet N, Pearman JW, Constable IJ, McAllister IL, Kennedy CJ, Isaacs T, Semmens JB; Team EPSWA. Management and outcomes of postoperative endophthalmitis since the endophthalmitis vitrectomy study: the Endophthalmitis Population Study of Western Australia (EPSWA)'s fifth report. Ophthalmology. 2005:112(7):1199-206 Comment in Ophthalmology. 2006;113(8):1472-3; author reply 1473.e1-2.

18. Recchia FM, Busbee BG, Pearlman RB, Carvalho-Recchia CA, Ho AC. Changing trends in the microbiologic aspects of postcataract endophthalmitis. Arch Ophthalmol. 2005; 123(3):341-6.

19. Schmitz S, Dick B, Krummenauer F, Pfeiffer N. Endophthalmitis in cataract surgery: results of a German survey. Ophthalmology. 1999;106(10):1869-77.

20. Serracarbassa PD, Serracarbassa LL, Rodrigues LD. Antibióticos intravítreos. Arq Bras Oftalmol. 2003:66(4):527-30

21. Shah GK, Stein JD, Sharma S, Sivalingam A, Benson W, Regillo CD, et al. Visual outcomes following the use of intavitreal steroids in the treatment of postoperative endophthalmitis. Ophthalmology. 2000;107(3):486-9. Comment in Ophthalmology. 2001;108(2): 240-1.

22. Results of the Endophthalmitis Vitrectomy Study A randomized trial of immediate vitrectomy and of intravenous antibiotics for the treatment of postoperative bacteria endophthalmitis. Endophthalmitis Vitrectomy Study Group. Arch Ophthalmol. 1995; 113(12):1479-96

23. West ES, Behrens A, McDonnell PJ, Tielsch JM, Schein OD. The incidence of endophthalmitis after cataract surgery among the U.S. Medicare population increased between 1994 and 2001. Ophthalmology. 2005;112(8):1388-94
24. Wong TY, Chee SP. The epidemiology of acute endophthalmitis after cataract surgery in an Asian population. Ophthalmology. 2004;111(4):699-705. Comment in Ophthalmology. 2005;112(5):944; author reply 944.

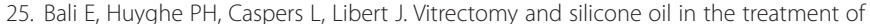
acute endophthalmitis. Preliminary results. Bull Soc Belge Ophtalmol. 2003:(288):9-14.

26. Mackiewicz J, Koziol-Montewka M, Kosior-Jarecka E, Szczepanik A, Wójtowicz M, Zagórski Z. [Evaluation of antimicrobial properties of silicon oil-in vitro studies]. Klin Oczna. 2004;106(3 Suppl):434-5. Polish.

27. Ozdamar A, Araz C, Ozturk R, Akin E, Karacorlu M, Ercikan C. In vitro antimicrobial activity of silicone oil against endophthalmitis-causing agents. Retina. 1999;19(2):122-6. Comment in Retina. 2001;21(1):92-3.

28. Soheilian M, Mazareei M, Mohammadpour M, Rahmani B. Comparison of silicon oil removal with various viscosities after complex retinal detachment surgery. BMC Ophthalmol. 2006;6:21.

29. Soheilian M, Rafati N, Mohebbi MR, Yazdani S, Habibabadi HF, Feghhi M, Shahriary HA, Eslamipour J, Piri N, Peyman GA; Traumatic Endophthalmitis Trial Research Group. Prophylaxis of acute posttraumatic bacterial endophthalmitis: a multicenter, randomized clinical trial of intraocular antibiotic injection, report 2. Arch Ophthalmol. 2007;125(4):460-5

30. Bauer AW, Kirby WM, Sherris JC, Turck M. Antibiotic susceptibility testing by a standardized single disk method. Am J Clin Pathol. 1966:45(4):493-6.

31. Tavares W. Manual de antibióticos e quimioterápicos antiinfecciosos. 2ª ed. São Paulo: Atheneu; 1996

32. Malta JN, Romero IL, Murca MA, Mimica LM, Dantas PE, Nishiwaki-Dantas MC, Hida RY. Antimicrobial study of the vital staining formulations used in ophthalmology [abstract]. ARVO. 2006:1921:B282.

33. De Almeida Manzano RP, Naufal SC, Hida RY, Guarnieri LO, Nishiwaki-Dantas MC. Antibacterial analysis in vitro of ethyl-cyanoacrylate against ocular pathogens. Cornea. 2006:25(3):350-1

34. Romero IL, Paiato TP, Silva CB, Nigro JB, Malta S, Jenne Mimica LM, et al. Different application volumes of ethyl-cyanoacrylate tissue adhesive can change its antibacterial effects against ocular pathogens in vitro. Curr Eye Res. 2008;33(10):813-8.

\title{
XIX Simpósio Internacional de Atualização em Oftalmologia da Santa Casa de São Paulo
}

\author{
15 e 16 de junho de 2012 \\ Instituto de Ensino e Pesquisa do \\ Hospital Sírio-Libanês (IEP) \\ São Paulo (SP)
}

Informações: 